\title{
Defining transformative climate science to address high-end climate change
}

\author{
J. David Tàbara ${ }^{1}$ (D) $\cdot$ Jill Jäger ${ }^{2} \cdot$ Diana Mangalagiu $^{3} \cdot$ Marco Grasso $^{4}$
}

Received: 17 October 2016 / Accepted: 22 January 2018 /Published online: 12 February 2018

(C) The Author(s) 2018. This article is an open access publication

\begin{abstract}
High-end climate change requires transformative solutions, as conventional strategies and solutions will not be enough if major disruptions in social-ecological systems are to be avoided. However, conventional climate assessment approaches and methods show many limitations if they are to provide robust knowledge and support to the implementation of such solutions in practice. To this end, we define transformative climate science as the open-ended process of producing, structuring, and applying solutionsoriented knowledge to fast-link integrated adaptation and mitigation strategies to sustainable development. In particular, based on our experiences within regional cases in Central Asia, Europe, Iberia, Scotland, and Hungary, we have selected 12 dimensions that scientists and practitioners can use as a checklist to design transformative-oriented climate assessments. While it is possible to talk both about transformative adaptation and transformative mitigation, in this paper, we make the case that societal transformation does not depend on mitigation or adaptation policies and actions, mostly because they are related to sustainability innovations, which are endogenous developments derived from deliberate social learning
\end{abstract}

Keywords Transformative solutions and pathways $\cdot$ High-end climate change $\cdot$ Sustainable development

\section{Introduction}

Although the Nationally Determined Contribution (NDC) part of the Paris Agreement testifies to an unprecedented global breadth of climate initiative, they did not set sufficient emission cuts to achieve the main goal of limiting the global temperature increase "well below" $2{ }^{\circ} \mathrm{C}$ while pursuing $1.5^{\circ} \mathrm{C}$ by

J. David Tàbara

joandavid.tabara@uab.cat

Jill Jäger

jill.jaeger@speed.at

Diana Mangalagiu

diana.mangalagiu@ouce.ox.ac.uk

Marco Grasso

marco.grasso@unimib.it

1 Autonomous University of Barcelona, Campus UAB, 08193 Cerdanyola del Vallés, Spain

2 Independent Scholar, Vienna, Austria

3 NEOMA Business School, Mont-Saint-Aignan, France

4 Universita degli Studi di Milano-Bicocca, Milan, Italy the end of the century; the safe levels also reported in Article 2 of the treaty (Peters et al. 2017; Hallegatte et al. 2016; Allen 2015). On the one hand, the lack of enforcement mechanisms and the weakness of the implementation instruments of the Agreement make it very likely that this threshold will be surpassed. On the other hand, the absence of integrated strategies for climate change, explicitly aimed at institutional change and aligned with the achievement of the Sustainable Development Goals, will make climate trends also likely to worsen. In these conditions, it is increasingly clear that conventional solutions will not be enough to prevent the world moving towards global warming scenarios of $4{ }^{\circ} \mathrm{C}$ or even $6{ }^{\circ} \mathrm{C}$ by 2100 . New science-policy assessment processes and modes of agent interaction, engagement, and knowledge coproduction are needed (Boucher et al. 2016; Hulme 2016; Tàbara et al. 2017). Required in particular are those with an orientation towards transformation and which go beyond the traditional sectoral, additive, and linear projections (still present in the IPCC Fifth Assessment Report), and which are able to show a move towards more integrated, cross-sectoral, multiplicative, and non-linear developments. The overall goal of this paper is to set the conceptual basis for the development of such open and engaging integrated assessment (IA) procedures to support the implementation of systems of situated 
solutions and transformative capacities in the context of a rapidly warming world.

The kind of transformative solutions required to address a global warming beyond $2{ }^{\circ} \mathrm{C}$ or high-end climate change (HECC; Berry et al. 2017) is likely to be those that are able to deal with the ultimate causes of the current climate crisisnamely the growing unsustainability of present global systems' trends and by doing so, to create synergies between climate action and the achievement of a good quality of life and of sustainability in general (Hackmann et al. 2014). In fact, many of the most important transformative social forces now visible in many regions of the world with a positive effect on climate change mitigation or adaptation often occur outside, or happen independently from, the United Nations climate negotiations. Hence, innovative climate strategies and solutions could take advantage of and support a number of local transformative initiatives not necessarily or explicitly driven by climate concerns. This is why in this article we argue that even in the context of HECC, transformation does not depend either on mitigation or adaptation policies and actions. However, understanding and connecting climate strategies to societal transformations are necessary conditions to support the kind of profound institutional reconfigurations required to deal with HECC and realign global systems trends towards sustainability. Transformative solutions to respond to HECC can only emerge as processes of social learning, whereby experimentation, openness, reflection, and strong collaboration are central tenets for the emergence of new sustainable patterns of socialecological interaction at planetary scale.

Therefore, the concepts of transformation and transformability are central to the development of new assessment research and policy approaches aimed at dealing with HECC. However, a systematic understanding of the meaning and implications of transformation both for science and policy practices - and societal innovations at large - under the new climatic conditions is still lacking. The broad range and diversity, polysemy, and different understandings of transformation and transformability limits their concrete use both in the design of research and assessment processes as well as in the actual implementation of potential strategies to deal with either mitigation or adaptation. Here, we use the notions of transformation and transformability to refer to fundamental institutional and system changes needed to align development to sustainability (Fleurbaey et al. 2014). A special emphasis is placed on the identification of potential synergies and trade-offs between sustainable development policies and climate policies. Within the IPCC, it is argued that "transformation pathways need to yield deep reductions in GHG emissions and should be based on iterative learning" (Clarke et al. 2014). In particular, it is stated that "the more ambitious the stabilization goal, the more rapid this transformation must occur" and that "transformation pathways to long-term climate goals are best understood as a process of sequential decision-making and learning" (Clarke et al. 2014). Nevertheless, the IPCC economic approaches to assessing transformation pathways still heavily rely on traditional cost-benefit analyses. That is, analyses that are mostly based on top-down, linear and optimality based appraisal methods for a single representative agent. This raises a number of limitations, already acknowledged by the IPCC, through using existing tools and methods to represent transformations and even more to assess solutions aimed at supporting such transformations (Minx et al. 2017). In fact, "the difficulty in representing these (transformation) processes in models has meant that societal change research has often been divorced from the literature on transformation pathways" (Clarke et al. 2014).

In the research reported herein, we address this challenge by operationalising the notion of transformative climate science (TCS) and provide 12 key dimensions that can be considered by scientists and policymakers interested in producing robust solutions-oriented knowledge for transformation. Our arguments are based on the insights from the EUsupported project IMPRESSIONS, ${ }^{1}$ aimed at co-producing transformative strategies and solutions in the context of HECC. Finally, we also discuss the limitations of this novel science-policy perspective.

\section{Transformation, sustainability, and transformability}

In the IPCC 2012 Special Report on Managing the Risks of Extreme Events and Disasters to Advance Climate Change Adaptation ("SREX report"), transformation was referred to as "the altering of fundamental attributes of a system (including value systems; regulatory, legislative, or bureaucratic regimes; financial institutions; and technological or biological systems)" (Field et al., 2012). The definition provided by the IPCC AR5 was similar but slightly different: transformation was defined as "a change in the fundamental attributes of natural and human systems [that] reflects strengthened, altered, or aligned paradigms, goals, or values towards promoting adaptation that supports sustainable development, including poverty reduction" (Field et al., 2014). This later definition introduced a more pluralistic understanding of transformation and the word "regimes" was no longer there, while the words sustainable development and poverty reduction were included. These modifications, which often go unnoticed, have important and positive implications, mostly because the AR5 definition: (i) was more attuned with achieving the Sustainable Development Goals (SDG); (ii) was more conducive to thinking in terms of multiple systems of interlinked distributed solutions (and not only one); (iii) helped to avoid redundancies, ambiguities, and contradictions between "regimes" and "systems"; and (iv) included a basic economic component of poverty reduction, which is also more aligned

\footnotetext{
${ }^{1}$ www.impressions-project.eu.
} 
with the development of innovative solutions from an ethical, political, and distributional stance.

In addition, several authors have underlined how the concepts of transformation and transformability contrast with those of adaptation and adaptability. According to Olsson et al. (2014), "transformability refers to the social-ecological capacities that enable shifts from one regime to another, and adaptability refers to the capacities to deal with change and stay within a regime." Likewise, Folke et al. (2010) define resilience as capacity of a social-ecological system: "to continually change and adapt yet remain within critical thresholds." Adaptability is part of resilience. It represents the capacity to adjust responses to changing external drivers and internal processes and thereby allow for development along the current trajectory (stability domain) [while transformability is the] "capacity to cross thresholds into new development trajectories" (see also Feola 2015; Pelling \& O'Brien 2015; Gunderson \& Holling 2002). Transformability constitutes a system property derived from agents' actions, which can structure the system in a way that either make adaptation and change processes inherent to the system or create policies that obstruct change. Thus, the system is either more or less able to undergo continuous transformation. Such a relational property derived from agents' transactions and structure configurations has to contend with: (1) the capacities and abilities of agents to transform the system (and themselves) deliberately and (2) the capacity, degrees of freedom, and potential of the system to be transformed and induce continuous transformation - through learning and enhanced collective reflectivity. It should be noted that transformability is not opposed to resilience, as transformation capacities may be needed to ensure system resilience in the long-term. However, given the focus of our research and in order to avoid further confusions, we will limit the use of the notion of transformations to those profound system changes related to achieving sustainable development and likewise we will limit the concepts of adaptation and adaptability to those that have to do with climate change.

As it has been widely recognised in the literature, sustainable development is a highly controversial concept Kates et al., 2012). Many attempts have already been made to produce practical insights into how to operationalise this concept and link it to climate policies and actions (Tàbara 2011). Without addressing these lengthy debates, which are out of the scope of this article, we just want to underline that discussions in sustainability science are increasingly placing greater emphasis on the exploration of specific options for institutional transformations and transformability, i.e. the ability to create a new system when the prevalent goals of the existing one become unattainable (Burch et al. 2014; Burch 2010; Walker et al. 2009; Walker et al. 2004). Transformations are understood to encompass fundamental modifications in a set of institutions, including changes in property regimes (O'Brien 2012; Ostrom 2009; Ostrom, 2009), access to education and political systems (e.g. by women; see Elliot 2012), or the development of open knowledge systems to support social learning (Tàbara \& Chabay 2013; Cornell et al. 2013). In addition, research focusing on transformation and sustainability is advancing in the making of a richer representation of agency, mainly using more complex system perspectives in modelling as well as assessment tools and methods. In this guise, the need to understand and integrate the role played by values, visions, and conflicting interests is triggering a whole new array of methodological innovations with the purpose of developing more robust knowledge about possible transformative strategies and solutions supportive of sustainable development (Clark et al. 2016; van Kerkhoff and Lebel, 2006; van der Kerkhoff 2014; Miller 2013; Miller et al. 2013; Lynam et al. 2007). More broadly, this can be seen as part of a general trend to:

(i) Move from the traditional focus on the research question about "what is the problem," to exploring the question of "who is the solution" and to better understand of the role of agency (Westley et al. 2011; Westley et al., 2013), e.g. by promoting the institutionalisation of multiple networks working on systemic innovation and win-win solutions;

(ii) Consider how to redistribute long-term responsibilities accordingly (see Dangerman \& Schellnhuber 2013; Tàbara et al. 2010);

(iii) Move away from the development of climate policy narratives about additional costs, impacts, and burdensharing to those focused on opportunities (Jaeger et al. 2013); and

(iv) Focus new climate assessment processes on solutions that are able to yield multiplicative, non-linear, and systemic effects in contrast to the traditional additive, wedge-based, or single-sector/scale approaches (see Berry et al. 2015; Kates et al. 2012; Tàbara et al. 2013; Wiek et al. 2012).

\section{Defining transformative climate science}

TCS has not emerged in isolation. To a large extent, it is the result of the confluence of numerous integrative sciencepolicy approaches that started over three decades ago in the attempt to address a growing number and complexity of interlinked problems related to social and environmental change. Research adopting post-normal science (PNS), integrated assessment (IA), integrated sustainability assessment (ISA), transition management (TM), responsible research and innovation (RRI), science and technology studies (STS), and transdisciplinary science (TDS) approaches, among others, developed various approaches for opening up and ensuring the engagement of multiple kinds of stakeholders in processes at 
the science-policy interface. It has been claimed that the new designs would help the joint definition not only of societal and global issues at stake but also of solutions. In addition, they would also secure a more robust co-construction of valid knowledge, by yielding more adequate framings of the problems to be addressed. "Normal" or traditional procedures of science, amply influenced by positivist thinking, were unable to deal with the large-scale and irreducible uncertainties and the conflicts derived from assessments which inevitably had to include strong ethical and normative decisions (Jamieson 2014; Gardiner 2011; Owen et al. 2012; Rotmans et al. 2008; Funtowicz \& Ravetz 1991, Jäger 1998). With all this background, transformation research has been particularly taken up by sustainability science (Mauser et al. 2013; Miller 2013; Miller et al. 2013; Wiek et al. 2012; Ostrom 2009), and more recently, with the proposal of developing global systems science (GSS) (Jaeger et al. 2013), with special emphasis on finding "globally interconnected systems of solutions to global problems" of which climate change is but one. These approaches have contributed to introducing a transformation focus in climate assessment procedures in which the integration with sustainable development principles and goals is included. This entails a fundamental change in science-policy practices, e.g. by focusing on ultimate interlinked causes - and their cumulative non-linear consequences - of societal problems and system interactions. This change in orientation may also help to think ahead about how to deal with possible rebound effects or even more problems derived from conventional and partial solutions to climate mitigation and adaptation.

However, and despite this wide range of new research approaches, few have focused on processes explicitly oriented to designing transformative pathways under conditions of HECC. Following a terminology already used by Dusyk et al. (Dusyk et al., 2009), Table 1 provides 12 features, in the form of a checklist of contrasting characteristic practices, which can be used by scientists and practitioners to move from conventional to transformative approaches in the assessment and implementation of climate strategies and solutions. Taken singularly, these are not "distinctive" or unique to TSC, as the various strands of sustainability-oriented approaches mentioned before are already embracing many of these. However, these elements can be taken as practical requirements to produce more robust knowledge on solutions and strategies aimed at addressing HECC. On the one hand, we are talking about how the pathways of solutions are developed - not the pathways themselves. On the other, not all features are necessarily symmetric or opposed to each other. For example, first-order learning is not opposed to secondorder learning. The table can be read as containing idealtype characterisations of actual climate assessment practices. Moreover, we argue that this conceptual framework is better suited than the distinction that it is often used between "transformational" and "incremental" (as in the SREX report).
Using the term "incremental" as opposed to the transformative can be misleading, given that the notion of incremental may only refer to the speed of change rather than the actual nature of the change in the overall configuration of the system. ${ }^{2}$

These dimensions can be described as follows:

1) Representation of agency in economic modelling: An accurate representation of agents' behaviour and dynamics using a complexity perspective and heterogeneous agency is a crucial component to improve current macroeconomic tools and methods used in the assessment of options and innovative solutions to HECC. Agent-based modelling, system dynamics, and science-policy approaches looking at emergence and multiple kinds of agents' rationalities beyond single utility maximisation could play a central role in this endeavour and in particular in showing potential cooperation mechanisms required for systems' transformation (Epstein 2012; Preston et al. 2015).

2) Assessment of options for change of institutional, behavioural and social-ecological systems interactions: Transformative assessment tools and methods ought to evaluate and provide a portfolio of feasible options for institutional and behavioural transformations. Such assessment needs to be based on a robust representation of core system interactions and the systemic effects of transformations in agents' behaviours so both climate and sustainability imperatives are met (Tàbara et al. 2010, Koontz et al. 2015).

3) Systems of systems approach: Most current models and assessment procedures tend to take a sectoral approach or deal only with one kind of system or sector-food, mobility, health, finance, population, and information, so little is known about the interconnected effects of multiple kinds of systems operating under different unique dynamic configurations. Promising approaches such as those looking at a system nexus and the application of a "nexus governance" (Al-Saidi \& Elagig 2017; Boas et al. 2016) are emerging in this regard, including also GSS, understood as the search for and assessment of "global systems of interconnected solutions" (Jaeger et al., 2013; Helbing 2013).

4) Assumptions about the future attainability of existing systems goals: Many advocates who believe that technological solutions (including geoengineering) would suffice to cope with climate change tend to assume that

\footnotetext{
${ }^{2}$ Hence, it is possible to talk of strategies that are both non-transformative and fast (e.g. the bail-out of the US banks that kept most of global financial system intact) or incremental but transformative strategies, if they aim at fundamentally changing the attributes of a given system. Similarly, the rather transformative proposal of keeping most of the remaining fossil fuels in the ground, eliminating perverse energy subsidies and redirecting the extra revenue to sustainable development goals could be taken in an incremental strategy.
} 
Table 1 Contrasts between conventional versus transformative approaches in the assessment of pathways, strategies, and solutions to high-end climate change

\begin{tabular}{|c|c|c|}
\hline Dimension/approach & Conventional & Transformative \\
\hline $\begin{array}{l}\text { 1. Representation of agency in economic } \\
\text { modelling }\end{array}$ & Single rationality, single representative agent & Heterogeneous agency, multiple rationalities \\
\hline $\begin{array}{l}\text { 2. Assessment of options for change of } \\
\text { institutional, behavioural and social-ecological } \\
\text { systems interactions }\end{array}$ & Weak & Strong \\
\hline 3. Systems of systems approach and coordination & $\begin{array}{l}\text { Not necessary or minimal; only dealing with one } \\
\text { system or sector or very few at a time }\end{array}$ & $\begin{array}{l}\text { Fundamental; dealing with multiple systems or } \\
\text { sectors at a time, e.g. nexuses between food, } \\
\text { energy, finance, health, mobility ... }\end{array}$ \\
\hline $\begin{array}{l}\text { 4. Assumptions about the future attainability of the } \\
\text { existing system goals }\end{array}$ & $\begin{array}{l}\text { The present system goals are believed to be still } \\
\text { attainable in the future without profound } \\
\text { reconfigurations }\end{array}$ & $\begin{array}{l}\text { The present system goals are no longer believed } \\
\text { to be attainable in the future, and hence } \\
\text { require profound reconfigurations }\end{array}$ \\
\hline 5. Role of visions and normative futures & $\begin{array}{l}\text { Without visions: only exploratory/descriptive } \\
\text { (non-normative, non-directional) scenarios }\end{array}$ & $\begin{array}{l}\text { Including visioning processes which co-produce } \\
\text { desirable futures within the assessment } \\
\text { process (to trigger and orient change) }\end{array}$ \\
\hline $\begin{array}{l}\text { 6. Representation of system dynamics. Role of } \\
\text { multiple feedbacks, cumulative processes, and } \\
\text { irreversibilities, including tipping points, phase } \\
\text { transitions, bifurcations ... }\end{array}$ & $\begin{array}{l}\text { Linear representation of system dynamics; } \\
\text { multiple feedbacks, cumulative processes, and } \\
\text { irreversibilities, including tipping points, } \\
\text { phase transitions, bifurcations, rarely or not } \\
\text { considered (or weakly so) }\end{array}$ & $\begin{array}{l}\text { Non-linear and complex (e.g. multiple kinds of } \\
\text { non-linear interactions; assessing emergence); } \\
\text { multiple feedbacks, cumulative processes, } \\
\text { and irreversibilities, including multiple } \\
\text { tipping points, phase transitions, bifurcations, } \\
\text { strongly considered }\end{array}$ \\
\hline $\begin{array}{l}\text { 7. Time and space scales considered at the same } \\
\text { time }\end{array}$ & Single; cumulative effects scantily addressed & $\begin{array}{l}\text { Multiple; including cumulative effects of past } \\
\text { and present actions at various scales }\end{array}$ \\
\hline 8. Uncertainty (assumptions and treatment) & $\begin{array}{l}\text { Low/medium; probability distributions assumed } \\
\text { to be known (e.g. as risks). Probabilism }\end{array}$ & $\begin{array}{l}\text { High and very high; probability distributions } \\
\text { mostly unknown, (e.g. as indeterminacies). } \\
\text { Possibilism }\end{array}$ \\
\hline 9. Kind of learning required & First-order (doing the same better and more) & $\begin{array}{l}\text { Second-order (doing something different under a } \\
\text { different paradigm) }\end{array}$ \\
\hline 10. Expected outcomes of the assessment & $\begin{array}{l}\text { Single optimal solutions based on a single } \\
\text { equilibrium; win-lose solutions (e.g. burden } \\
\text { sharing) }\end{array}$ & $\begin{array}{l}\text { Multiple win-win solutions, multiple winners, } \\
\text { based on multiple equilibria; integrated } \\
\text { strategies for addressing multiple } \\
\text { interconnected problems }\end{array}$ \\
\hline 11. Assessment of equity and distributional issues & $\begin{array}{l}\text { Weakly considered (e.g. only intragenerational } \\
\text { equity) }\end{array}$ & $\begin{array}{l}\text { Strongly considered (including both intra- \& } \\
\text { intergenerational equity) }\end{array}$ \\
\hline $\begin{array}{l}\text { 12. Criteria tools and methods used in the design } \\
\text { and assessment of solutions and strategies }\end{array}$ & $\begin{array}{l}\text { One or very few criteria considered, mostly } \\
\text { profitability or/and (eco)efficiency }\end{array}$ & $\begin{array}{l}\text { Multicriteria tools and methods promoted, to } \\
\text { consider multiple criteria besides profitability. } \\
\text { These include (eco and/or social) } \\
\text { efficiency + sufficiency + sustainability. }\end{array}$ \\
\hline
\end{tabular}

the existing institutional, production, and consumption systems can continue functioning without major fundamental transformations in their configuration. This view contrasts with a position in which research is focused on exploring and supporting alternative ways of socioecological system reconfigurations based on the assumption that their goals are no longer attainable or no longer viable in the future as they are now constituted (Moore et al. 2014; Pelling, O’Brien and Matyas 2015).

5) Role of visions and normative futures: The development of climate assessment processes in TCS needs to integrate the role of explicit normative visions (the future we want) and subjective judgments on transformative futures in reorienting policy strategies at various scales of action. This entails a perspective which acknowledges the intersubjective formation of meanings and motives and a co-production process can only be done in a participatory way (Maggs \& Robinson 2016; O'Brian 2016; Campos et al. 2016; Pereira et al. 2015; Inderberg et al. 2014; Weaver et al. 2006).

6) Representation of system dynamics: Current emission trends make it increasingly likely that the $2-^{\circ} \mathrm{C}$ threshold will be exceeded, and this could lead to large-scale, nonlinear, and unpredictable changes in global socialclimate systems. However, little is known about how to assess multiple social feedbacks, irreversibilities, and cumulative effects of individual actions and bounded rationalities at global level, which include the potential of multiple tipping points - both positive and negative-phase transitions, bifurcations, chain cascades, 
and others. These complex dynamics need to be linked with the assessment of existing agents' capacities to cope with them. Assessing potential solutions and strategies to address HECC requires a more in-depth understanding of these more complex system dynamics.

7) Time and space scales considered at the same time: A more transformative approach would focus on making explicit the synergies and trade-offs associated with implementing solutions at different time scales and in connecting their consequences at different spatial scales. Transforming global energy systems or global resource consumption patterns or even restoring global ecosystems may take many decades or even centuries. However, the implications and distributive effects of such possible strategies - such as keeping most of the remaining fossil fuels in the ground - need to be clearly accounted for, both spatially and temporally.

8) Assumptions and treatment of uncertainty: The more conventional approaches to risk assessment tend to be based on using probabilistic methods. However, in a situation of HECC, the uncertainties are so high and the changes are complex and non-linear that conventional approaches to risk assessment cannot be used. In a context of HECC, a range of plausible options and their potential consequences need to considered, e.g. using scenarios. That is, possibilism is then favoured as probability distributions are mostly considered to be unknown (e.g. as indeterminacies).

9) Kind of learning required: first-order learning refers to doing the same, but better, more or faster. Second-order learning refers to doing something fundamentally different and from a different cognitive and normative perspective or paradigm. The latter includes changes in agents' modes of interaction, e.g. via institutional innovations. TCS could help sustainability learning, a class of second-order learning aimed at transforming socialecological interactions in a viable way, so as to ensure a good quality of life and maintenance of life-support systems in the long run (Tàbara \& Pahl-Wostl 2008).

10) General approach and expected outcomes: Conventional methods in macroeconomics tend to look for optimal solutions and consider climate policy as a cost and as a deviation from a single general equilibrium. This makes the assessment of multiple win-win solutions, new opportunities for green-growth, and transformations and non-market values very difficult (Tàbara et al. 2013; Tinch et al. 2015; Stern 2016). In TCS, there is no need to search for one single optimal solution, but to rather assess "systems of coupled solutions." What is needed is to envision and consider potential solutions (in plural) that are consistent with local values and culture, while contributing coherently to global sustainability.
11) Assessment of equity and distributional issues: A central component in the development of TCS is equity-both between generations (intergenerational equity) and in every generation (intragenerational equity) and both in terms of distributive equity and procedural equity (Grasso 2007). Conventional methods face many practical limitations to the inclusion of plural sources of equity considerations in climate assessments and thus more inclusive, procedural, and context-based approaches are required (Grasso and Sachhi 2015)—so as to ensure also the accountability of both procedures and outcomes of the assessments.

12) Criteria used in the design and assessment of solutions and strategies: One or very few criteria are considered in the design of conventional solutions and strategies to climate change, e.g. profitability or (eco)efficiency, because they can boost economic, personal, and environmental gains without necessarily requiring institutional change. For transformative solutions and strategies, multiple criteria are taken into account (e.g. using multicriteria methods) and include, among others, sufficiency (setting limits to consumption and promoting demand management of resources, e.g. to fossil fuels) and environmental sustainability (adapting societies to biophysical and ecosystems requirements).

Very few if any of these criteria are met in conventional climate change assessment processes. TCS involves a different way of positioning researchers' roles with respect to the "objects and "subjects" of study. TCS demands different modes of interacting with knowledge-holders. That is, the researchers are not experts detached from the communities of action where solutions need to be developed but more facilitators and integrators of multiple sources of co-created knowledge to support action. Nevertheless, there is still a long way to go for integrated climate research to move away from exploring "transformation pathways" mainly using conventional approaches (hence being "transformational"), to actual exploring and developing "transformative solutions" from a completely fresh theoretical and policy-oriented perspective as proposed in TCS, as summarised in Box 1.

In addition, implementing transformative solutions to HECC also requires profound changes in mind frames and worldviews. Many of the present cultural, cognitive, and ethical boundaries that prevail in much of the ethos driving agents' actions in present political, economic, and social systems must be overcome. As part of a broader social learning process, TCS requires extending the current science and policy cultural frames, dominant modes of thinking and ways of acting upon social-ecological systems to modify fundamentally the dominant bounded rationalities, and normative references used in individual and collective decision-making. This requires a transformation also in the way climate 
Box 1 Transformative climate science (TCS) as a social learning process which ...

- Focuses on solutions, not only on problems and trends;

- Integrates and promotes reflectivity on individual motives, beliefs, values, human nature and agency, e.g. via normative visions;

- Focuses on deep causes and social-ecological interactions (mainly global systems unsustainability), not only on symptoms;

- Links local/situated integrated solutions of multiple problems to global processes;

- Supports the coordination of 'global systems of solutions' to support sustainable development;

- Moves from a sectoral, incremental approach about solutions to an integrated, multiplicative, non-linear approach;

- Aims to understand and support agents' transformative capacities;

- Helps to redistribute rights and responsibilities and addresses institutional, behavioural change and fundamental equity issues;

- Responds to two central questions:

- In transdisciplinary research: understanding "Who is the solution?," rather than "What is the problem?"

- Specifically for modelling: how to represent (heterogeneous) agent interactions, multiple rationalities, cumulative/recursive effects, leverage points, systems learning (as an emerging property), and ethical considerations?

assessment processes are framed and carried out (Fig. 1) so that new practices:

(i) Take a long-term adaptive perspective into account: e.g. more than 5-15 generations, as systems may take a long time to change or be restored to cope with HECC. Both short- and mid-term implications of win-win solutions need to be considered within long-term strategies.

(ii) Use a global systems view: trade-offs and synergies between global and local/regional solutions and global strategies need to be assessed, and

(iii) Overcome the many cultural dualisms and opposed identities between the value of humans and the value of the non-human world and ecosystems: e.g. move away from the framing that sees climate change as a problem "of the environment out there" rather than an intrinsic human, political, and economic one.

Therefore, TSC can be understood as a transdisciplinary endeavour aimed at providing some practical guidance to both climate scientists and practitioners to develop concepts, tools, and methods that are more fit for the quest of developing robust strategies and solutions to the fast accelerating and closely intertwined climate and sustainability challenges. Hence, it may not necessarily be so much about identifying general axiomatic truths-although some are needed such as the assumption that conventional approaches are not enough to deal with HECC. Instead, it is mostly about identifying the processes and key elements that would be needed to share insights, support social learning, and improve the societal relevance and quality of the assessments aimed at supporting societal transformations so that they take climate and sustainability challenges into account in the context of HECC. In this way, TCS operates at the interface of climate and social sciences, using a solution orientation, rather than a curiosity-driven orientation (see Hulme 2016); and in this sense, it is neither "basic science" nor pure "implementation" but both at the same time. For these reasons, TCS is not necessarily opposed to more conventional approaches but complementary to them.

TCS has, however, some clear limitations. In particular, TCS should not be understood as another form of "promissory science" nor it can claim to be the solution to all of our global systems problems. Hence, it can also be argued that the purpose of climate science is not that of facilitating transformation. But any attempt to support transformation without the necessary robust knowledge on what can be done to achieve an improved situation would also be worthless or even create even a larger number and more acute kinds of problems. The ambition of TSC is not to produce full-fledged, universal, one size-fits-all solutions and strategies to the problem of global climate change either (such as the optimal solutions generated by the general equilibrium macroeconomic models). But rather to provide the necessary epistemological reflectivity to examine critically the existing concepts, tools, and methods and support science-policy processes so that more situated and robust kinds of knowledge can be generated; and to do so to identify, frame, and assess such solutions in concrete and diverse contexts of action. Hence, we do not claim to have the final word but just to start a much-needed conversation. In any case, the final outcomes of this proposed approach will be largely contextual and dependent on the iterative process designs in which knowledge deliberation and integration take place. We cannot even assume that it will succeed in energising all the required capabilities and social forces needed to rebuild the institutional milieu to adapt to and mitigate the effects of the new global climatic situation. But as an open mode of precautionary science and learning, it could provide guidance to set the basis for a more integrated systems reflectivity to deal with the endangerment of the basic conditions for human survival as we know them today. It may also be an approach contributing to the development of global system solutions through inclusive, robust knowledge production from diverse local contexts.

\section{Discussion}

While addressing climate change can become a transformative driver by itself, transformative solutions at a global system 
Fig. 1 Extended cognitive and normative framework of action for the development of transformative integrated solutions to high-end climate change. Source: adapted from (Tàbara 1999)

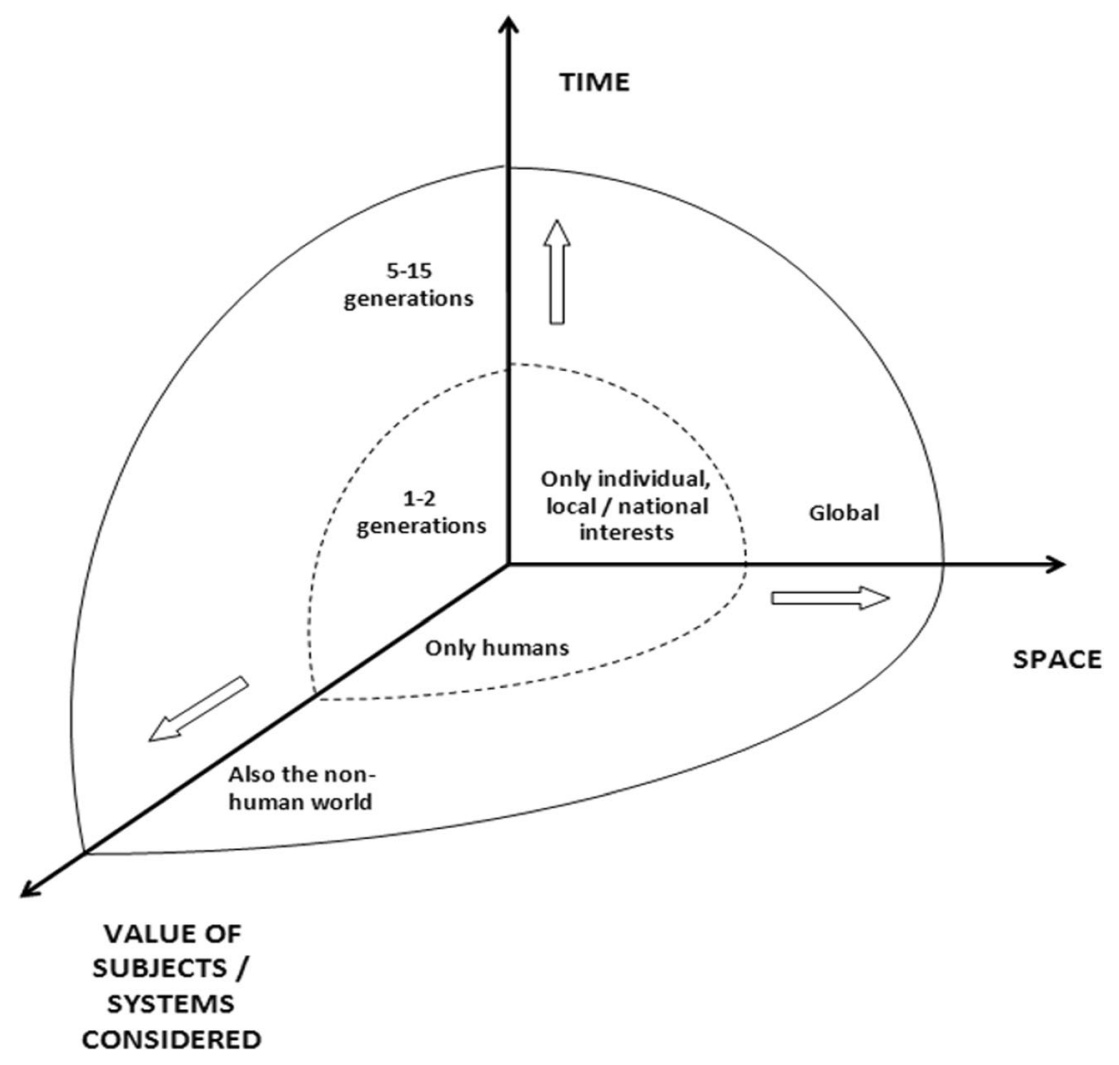

level are bound to be triggered from forces outside the climate domain. We understand transformation as an independent dimension, albeit potentially connected to either mitigation or adaptation to climate change. The reason for that is that positive transformations, as those envisioned in sustainability thinking and practice, tend to be the result of endogenous developments and deliberate social learning, instead of being determined by external forces. Thus, TCS efforts need to be placed to better understand the internal forces, visions, agents' capacities, and conditions that have better chances to trigger positive transformative changes aligned with sustainability. And do so in ways that connect them to climate policy narratives aimed at finding and implementing innovative solutions to HECC.

Our distinction between conventional versus transformative science-policy approaches can also be used to categorise different mitigation and adaptation strategies, as represented in Fig. 2.

That is, and in contrast to conventional adaptation and conventional mitigation, "transformative adaptation" and "transformative mitigation" would be purposefully oriented to modify fundamentally the attributes and global conditions in which particular agents and system interactions occur and align such climate actions to sustainable development. Moreover, it can be argued that, as we move to a more highend climate world (represented in red), the urgency of assessing and implementing transformative solutions is greater, although such solutions will not necessarily be implemented because of the climate threat-but only if societies want to achieve an improved world situation. Hence, the most innovative, robust, and persistent solutions to HECC are likely to be those which contribute to building the appropriate conditions and capacities to support sustainable development. After all, climate change may be understood not as the ultimate cause of any particular problem - and only an amplifier-but simply as a symptom of unsustainability. Narrowing the framing of global warming to a problem of GHG emissions leaves too many issues aside that need to be addressed if more transformative and long-lasting solutions are to be found to cope with HECC.

In this paper, we started with a strong normative assumption by stating that climate science should embrace more transformative-oriented approaches, but only if such assessment work is explicitly intended to provide robust knowledge on practical solutions and strategies to address high-end climate change. Hence, we do not claim that all climate science inquiry should follow that path, and we agree that a curiositydriven, open, and non-implementation-oriented research should still be encouraged - as after all, it is also the necessary basis for a more transformative perspective and practice. The core argument of the paper is that in conditions of HECC if science is to contribute not only to describing the problems but to the design of credible and robust assessments of its possible solutions, a more transformative approach is needed. In 
Fig. 2 Mapping out different conceptual approaches to adaptation, mitigation, and transformation

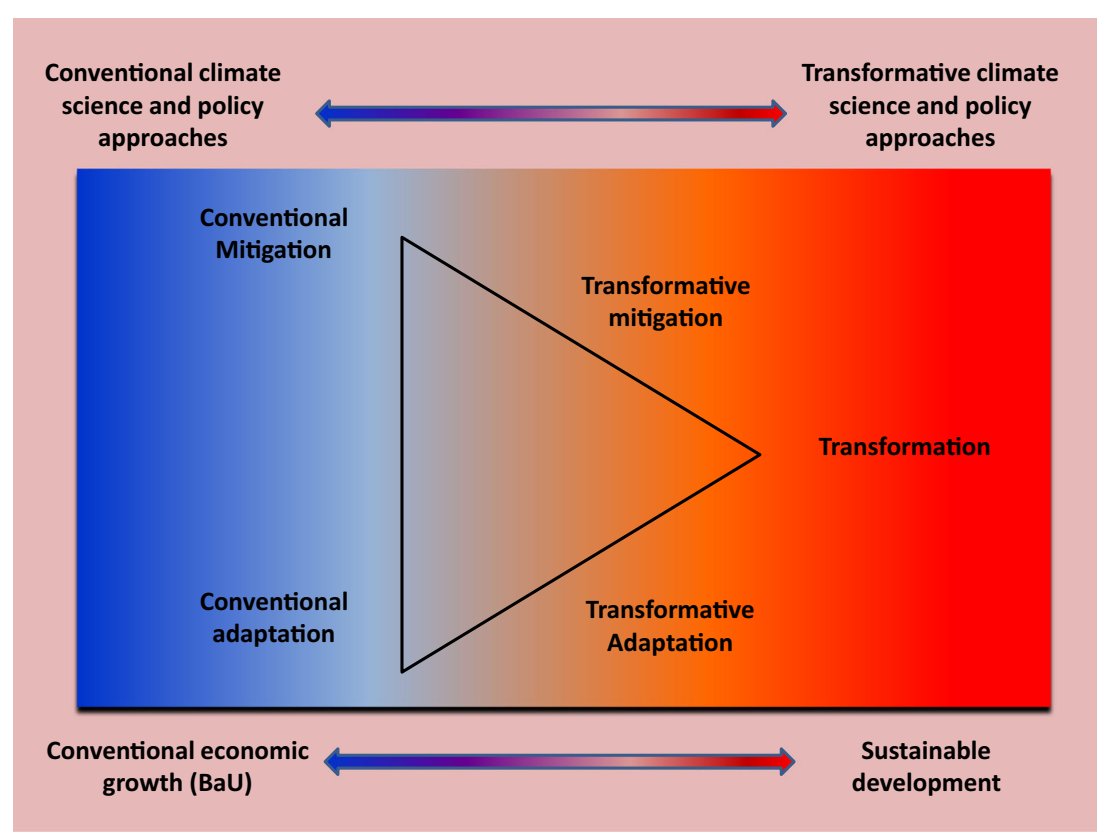

practice, this means not just doing more of the same but doing something radically different both in science and policy practice - which is what has been put forward in the description of the various elements in Table 1 .

\section{Conclusion: how transformable are human societies in the face of high-end climate change?}

In this paper, we provided a reflection on how to overcome the limitations of existing concepts, tools, methods, and processes being used in the framing, assessment, and implementation of solutions in the context of high-end climate change; and in particular, the need to develop a space for a science-policy interface aimed at supporting transformation. To a large extent, climate science has developed both as a "regime" and as an "isolated expert mindset" detached from the object of studywhich is people and society in their biophysical interactions. This is precisely what the various (normative) dimensions captured in Table 1 want to underline (and prevent). In this regard, TCS only seeks to show some procedural elements to develop "science in context, and co-produced with and for society at large"; that is, a kind of civic climate science which, in our case and in the context of high-end climate change, is oriented to support transformations. A crucial aspect in transformation processes is to support transformative capacities, which entails developing a sense of ownership of the policy narratives which are to be co-created and used to reorient action in concrete regional and local contexts. This demands a clear identification of the agents in charge of participating in the assessment processes and in taking the attendant climate-related decisions and actions. In this regard, a key challenge for the design of climate transformative strategies would be to expand and reframe the main current focus of climate research from the conventional and limited question about "what is the problem" (or impacts, risks, and vulnerabilities) to "who is the solution." This includes on the one hand, the support of open processes that would allow for a joint definition not only of the problems, but above all, for the development of concrete opportunities and agent capacities for change. Ensuring the openness of knowledge systems for citizens to participate in the design and implementation of practical solutions to improve their quality of life and cope with current unsustainability trends, such as those leading to high-end climate change, may be one of the most transformative ways to move forward. In this regard, many questions for this new approach still remain unanswered and among these: How to best characterise and operationalise transformative dynamics in the context of high-end scenarios? With what criteria and tools? How to select, harmonise, and create synergies between various transformative solutions and strategies? How to deal with cross-scale interactions? How to identify the main triggers, leverage points and conditions for system change, and institutional and behavioural learning? How to ensure accountability and fair representation? ...

Hence a consequent overarching question streaming from them is not only how adaptable are human societies to global warming but also mostly how transformable are contemporary global systems to achieve a situation which follows a desired and positive vision of the future, even in the impending situation of HECC? We have argued that TCS will only be able to contribute to the development of decisive systems' innovations to cope with HECC if the innovations are linked to main global social transformative forces already 
evident outside the climate domain. In the context of HECC, conventional strategies and solutions will not be enough and are likely to reinforce current unsustainability trends. Then, a main challenge is to explore the implications for climate science and policy of existing or potential transformative forces in ways which can be connected to integrated solutions on the ground that are able to support sustainable development. In this regard, climate change can be seen not only as an amplifier of global risks and problems but also as a source of transformative opportunities for sustainable development, capable of improving global equity and boosting global governance capacities to cope with global problems. Transformationoriented research ought to be able to understand the necessary conditions for linking climate and sustainable development solutions emerging outside the climate domain. Or in few words, societies may only be transformable and embrace successfully the challenge of high-end climate change, if they are able to embrace the broader societal challenges posed by sustainable development.

Acknowledgements We would like to thank Sander van der Leeuw, Niki Frantzeskaki, Ilan Chabay, and Pam Berry for their constructive comments.

Funding information The research has received funding from the EU project IMPRESSIONS - Impacts and Risks from High-End Scenarios: Strategies for Innovative Solutions (www.impressions-project.eu; EC FP7/2007-2013 grant no. 603416).

Open Access This article is distributed under the terms of the Creative Commons Attribution 4.0 International License (http:// creativecommons.org/licenses/by/4.0/), which permits unrestricted use, distribution, and reproduction in any medium, provided you give appropriate credit to the original author(s) and the source, provide a link to the Creative Commons license, and indicate if changes were made.

\section{References}

Allen M (2015). Paris emissions cuts aren't enough - we'll have to put carbon back in the ground. The Conversation, 14 December 2015. Retrieved from: https://theconversation.com/paris-emissions-cutsarent-enough-well-have-to-put-carbon-back-in-the-ground-52175

Al-Saidi M, Elagib NA (2017) Towards understanding the integrative approach of the water, energy and food nexus. Sci Total Environ 574:1131-1139. https://doi.org/10.1016/j.scitotenv.2016.09.046

Berry PM, Brown S, Chen S, Kontogianni A, Rowlands O, Simpson G, Skourtos M (2015) Cross-sectoral interactions of mitigation and adaptation measures. Clim Chang 128:381-393. https://doi.org/10. 1007/s10584-014-1214-0.

Berry PM, Betts RA, Harrison PA, Sanchez-Arcilla A (Eds.) 2017. High-end climate change in Europe. Available at http:/highendclimateresearch.eu/

Boas I, Biermann F, Kanie N (2016) Cross-sectoral strategies in global sustainability governance: towards a nexus approach. Int Environ Agreements Polit Law Econ 16(3):449-464. https://doi.org/10. 1007/s10784-016-9321-1

Boucher O, Bellassen V, Benveniste H, Ciais P, Criqui P, Guivarch C, Le Treut H, Mathy S, Seferian R (2016) In: the wake of Paris Agreement, scientists must embrace new directions for climate change research. PNAS 113(27):7287-7290. https://doi.org/10. 1073/pnas. 1607739113

Burch S (2010). Transforming barriers into enablers of action on climate change: insights from three case studies in British Columbia, CanadaGlob Environ Chang, 20, 287-297, https://doi.org/10.1016/ j.gloenvcha.2009.11.009

Burch S, Shaw A, Dale A, Robinson J, Climate Policy (2014) Triggering transformative change: a development path approach to climate change response in communities. Clim Pol 14(4):467-487. https:// doi.org/10.1080/14693062.2014.876342

Campos IS, Alves FM, Dinis J, Truninger M, Vizinho A, Penha-Lopes G (2016) Climate adaptation, transitions, and socially innovative action-research approaches. Ecol Soc 21(1):13. https://doi.org/10. 5751/ES-08059-210113

Clark WC, van Kerkhoff L, Lebel L, Gallopin GC (2016) Crafting usable knowledge for sustainable development. PNAS 113(17):4570 4578. https://doi.org/10.1073/pnas.1601266113

Clarke LK, Jiang K, Akimoto M, Babiker G, Blanford K, Fisher-Vanden JC, Hourcade V, Krey E, Kriegler A, Löschel D, McCollum S, Paltsev S, Rose PR, Shukla M, Tavoni BCC, van der Zwaan, van Vuuren DP (2014). Assessing transformation pathways. In: Climate Change 2014: mitigation of climate change. Contribution of Working Group III to the Fifth Assessment Report of the Intergovernmental Panel on Climate Change In Edenhofer O, et al. Cambridge University Press, Cambridge, United Kingdom and New York, NY, USA. p.413-510.

Cornell S, Berkhout F, Tuinstra W, Tàbara JD, Jäger J, Chabay I, de Wit B, Langlais R, Mills D, Moll P, Otto I, Petersen A, Pohl C, van Kerkhoff L (2013) Opening up knowledge systems for better responses to global environmental change Project. Environ Sci Policy 28:60-70. https://doi.org/10.1016/j.envsci.2012.11.008

Dangerman ATJ, Schellnhuber HJ (2013) Energy systems transformation. PNAS 110(5):49-E558. https://doi.org/10.1073/pnas. 1219791110

Dusyk N, Berkhout T, Burch S, Coleman S, Robinson J (2009). Transformative energy efficiency and conservation: a sustainable development path approach in British Columbia, Canada. Energy Effic 22 (4): 387-400, https://doi.org/10.1007/s12053-009-9048-8

Elliott J (2012) An introduction to sustainable development. Routledge, London and New York

Epstein B (2012). Agent-based modeling and the fallacies of individualism. Models, Simulations, and Representations, 115-44.

Feola G (2015) Societal transformation in response to global environmental change: a review of emerging concepts. Ambio 44(5):376-390. https://doi.org/10.1007/s13280-014-0582-z

Field CB, Barros V, Stocker TF, Qin D, Dokken DJ, Ebi, KL, Mastrandrea MD, Mach KJ, Plattner GK, Allen SK, Tignor M, Midgley PM (eds.) (2012). Managing the risks of extreme events and disasters to advance climate change adaptation. A special report of Working Groups I and II of the Intergovernmental Panel on Climate Change. Cambridge University Press, Cambridge, UK, and New York, NY, USA

Field CB., Barros VR, Dokken DJ, Mach KJ, Mastrandrea MD, Bilir TE, Chatterjee M, Ebi KL, Estrada YO, Genova RC, Girma B, Kissel ES, Levy AN, MacCracken S, Mastrandrea PR, White LL (eds.). (2014). Summary for policymakers. In: Climate Change 2014: impacts, adaptation, and vulnerability. Cambridge University Press, Cambridge, United Kingdom and New York, NY, USA, pp. 1-32

Fleurbaey M, Kartha Bolwig S, Chee YL, Chen Y, Corbera E, Lecocq F, Lutz W, Muylaert MS, Norgaard RB, Okereke C, Sagar AD. (2014). Sustainable development and equity. In: Climate Change 2014: mitigation of climate change. Contribution of Working Group III to the Fifth Assessment Report of the Intergovernmental Panel on Climate Change [Edenhofer, O, et al. (eds.)]. Cambridge University Press, Cambridge, United Kingdom and New York, NY, USA. p.283-350 
Folke C, Carpenter SR, Walker B, Scheffer M, Chapin FS, Rockstrom J (2010). Resilience thinking: integrating resilience, adaptability and transformability. Ecology and Society 15, 20. https://doi.org/10. 5751/ES-03610-150420

Funtowicz SO, Ravetz JR (1991) A new scientific methodology for global environmental issues. In: Constanza R (ed) Ecological economics: the science and management of sustainability. Columbia University Press, New York, pp 137-152

Gardiner S (2011) Is no one responsible for global environmental tragedy? Climate change as a challenge to our ethical concepts. In: Arnold D (ed) The ethics of global climate change. Cambridge University Press, Cambridge, pp 38-59. https://doi.org/10.1017/ CBO9780511732294.003

Grasso M (2007) A normative ethical framework in climate change. Clim Chang 81(3-4):223-246. https://doi.org/10.1007/s10584-006-9158-7

Grasso M, Sacchi S (2015) Impure procedural justice in climate governance systems. EnvironValues 24(6):777-798. https://doi.org/10. 3197/096327115X14420732702699

Gunderson LH, Holling CS (eds) (2002) Panarchy. Understanding transformations in human and natural systems. Island-Press, Washington, 493p

Hackmann H, Moser SC, St Clair AL (2014) The social heart of global environmental change. Nat Clim Chang 4(8):653-655. https://doi. org/10.1038/nclimate2320

Hallegatte S, Rogelj J, Allen M, Clarke L, Edenhofer O, Field CB, Friedlingstein P, van Kesteren L, Knutti R, Mach KJ, Mastrandrea M, Michel A, Minx J, Oppenheimer M, Plattner G-K, Riahi K, Schaeffer M, Stocker TF, van Vuuren DP (2016) Mapping the climate change challenge. Nat Clim Chang 6(7):663-668. https://doi. org/10.1038/nclimate3057

Helbing D (2013) Globally networked risks and how to respond. Nature 497(7447):51-59. https://doi.org/10.1038/nature12047

Hulme M (2016) $1.5^{\circ} \mathrm{C}$ and climate research after the Paris Agreement. Nat Clim Chang 6(3):222-224. https://doi.org/10.1038/ nclimate2939

Inderberg TH, Eriksen S, O'Brien K, Sygna L (2014) Climate change adaptation and development: transforming paradigms and practices. Routledge, London

Jaeger C, Jansson P, van der Leeuw S, Resch M, Tàbara JD, Dum R (Eds.). (2013). Global system science orientation paper. Background material and synthesis. http:/www.gsdp.eu/about/ global-systems-science/

Jäger J (1998) Current thinking on using scientific findings in environmental policy making. Environ Model Assess 3(3):143-153. https:// doi.org/10.1023/A:1019066907165

Jamieson D (2014) Reason in a dark time: why the struggle against climate change failed - and what it means for our future. Oxford University Press, Oxford. https://doi.org/10.1093/acprof:oso/ 9780199337668.001.0001

Kates RW, Travis WR, Wilbanks TJ (2012) Transformational adaptation when incremental adaptations to climate change are insufficient. PNAS 109(19):7156-7161. https://doi.org/10.1073/pnas. 1115521109

van Kerkhoff L (2014) Developing integrative research for sustainability science through a complexity principles-based approach. Sustain Sci 9(2):143-155. https://doi.org/10.1007/s11625-013-0203-y

van Kerkhoff L, Lebel L (2006) Linking knowledge and action for sustainable development. Annu Rev Environ Resour 31(1):445-477. https://doi.org/10.1146/annurev.energy.31.102405.170850

Koontz TM, Gupta D, Mudliar P, Ranjan P (2015) Adaptive institutions in social-ecological systems governance: a synthesis framework. Environ Sci Pol 53:139-151. https://doi.org/10.1016/j.envsci.2015.01.003

Lynam T, De Jong W, Sheil D, Kusumanto T, Evans, K (2007) A review of tools for incorporating community knowledge, preferences, and values into decision making in natural resources management. Ecol Soc 12(1):5 [online] URL: http://www.ecologyandsociety.org/ vol12/iss $1 /$ art5/
Maggs D, Robinson J (2016) Recalibrating the Anthropocene: sustainability in an imaginary world. Environ Philos 13(2):175-194. https://doi.org/10.5840/envirophil201611740

Mauser W, Klepper G, Rice M, Schmalzbauer BS, Hackmann H, Leemans R, Moore H (2013) Transdisciplinary global change research: the co-creation of knowledge for sustainability. Curr Opin Environ Sustain 5(3-4):420-431. https://doi.org/10.1016/j.cosust. 2013.07.001

Miller TR (2013) Constructing sustainability science: emerging perspectives and research trajectories. Sustain Sci 8(2):279-293. https://doi. org/10.1007/s11625-012-0180-6

Miller TR, Wiek A, Sarewitz D, Robinson J, Olsson L, Kriebel D, Loorbach D (2013) The future of sustainability science: a solutions-oriented research agenda. Sustain Sci 9(2):239-246. https://doi.org/10.1007/s11625-013-0224-6

Minx JC, Callaghan M, Lamba WF, Gararda J, Edenhofer O (2017) Learning about climate change solutions in the IPCC and beyond. Environ Sci Pol 77:252-259. https://doi.org/10.1016/j.envsci.2017.05.014

Moore ML, Tjornbo O, Enfors E, Knapp C, Hodbod JA, Baggio A, Noström A, Olsson P, Biggs D (2014) Studying the complexity of change: toward an analytical framework for understanding deliberate social-ecological transformations. Ecol Soc 19(4):54. https://doi. org/10.5751/ES-06966-190454.

O'Brien K (2012) Global environmental change. II. From adaptation to deliberate transformation. Prog Hum Geogr 36(5):667-676. https:// doi.org/10.1177/0309132511425767

O'Brien K (2016) Climate change and social transformations: is it time for a quantum leap? Wiley Interdiscip Rev Clim Chang 7(5):618-626. https://doi.org/10.1002/wcc.413

Olsson P, Galaz V, Boonstra WJ (2014) Sustainability transformations: a resilience perspective. Ecol Soc 19(4):1. https://doi.org/10.5751/ES06799-190401

Ostrom E (2009) A general framework for analyzing sustainability of social-ecological systems. Science 324(5939):419-422

Owen R, Macnaghten P, Stilgoe J (2012) Responsible research and innovation: from science in society to science for society, with society. Sci Public Policy 39(6):751-760. https://doi.org/10.1093/scipol/scs093

Pelling M, O’Brien K, Matyas D (2015) Adaptation and transformation. Clim Chang 133(1):113-127. https://doi.org/10.1007/s10584-014-1303-0

Pereira L, Karpouzoglou T, Doshi S, Frantzeskaki N (2015) Organising a safe space for navigating social-ecological transformations to sustainability. Int J Environ Res Public Health 12(6):6027-6044. https://doi.org/10.3390/ijerph120606027

Peters GP, Andrew RM, Canadell JG, Fuss S, Jackson RB, Korsbakken JI, Le Quéré C, Nakicenovic N (2017) Key indicators to track current progress and future ambition of the Paris Agreement. Nat Clim Chang. Advance online publication. 7(2):118-122. https://doi.org/ 10.1038/nclimate3202

Preston BL, King AW, Ernst KM, Absar SM, Nair SS, Parish ES (2015) Scale and the representation of human agency in the modeling of agroecosystems. Curr Opin Environ Sustain 14:239-249. https:// doi.org/10.1016/j.cosust.2015.05.010

Rotmans J, Jäger J, Weaver P (2008) 'Editorial'. Special issue on integrated sustainability assessment. Int J Sustain Dev Innov 3(1/2):1-8

Stern N (2016) Economics: current climate models are grossly misleading. Nature 530(7591):407-409. https://doi.org/10.1038/530407a

Tàbara JD (1999). Acció ambiental. Aprenentatge i participació vers la sostenibilitat. (Environmental action. Learning and participating towards sustainability). Balearic Islands: di7 edició

Tàbara JD (2011). Integrated climate governance and sustainable development'. In: Jaeger, C. C. Tàbara, J. D. And Jaeger J. (2011). European research on sustainable development. Vol I: transformative science approaches for sustainable development. Heidelberg, Germany: Springer and European Commission, pages 91-109

Tàbara JD, Chabay I (2013) Coupling human information and knowledge systems with social-ecological systems change. Reframing research, 
education and policy for sustainability. Special Issue on "Responses to Environmental and Societal Challenges for our Unstable Earth (RESCUE)". Environ Sci Policy 28:71-81. https://doi.org/10.1016/ j.envsci.2012.11.005

Tàbara JD, Pahl-Wostl C (2008). Sustainability learning in natural resource use and management. Ecol Soc, 12 (2): 3. [online] URL: www.ecologyandsociety.org/viewissue.php?sf $=28$

Tàbara JD, Dai X, Jia G, McEvoy D, Neufeldt H, Serra A, Werners S, West JJ (2010) The climate learning ladder. A pragmatic procedure to support climate adaptation. Environ Policy Gov 20(1):1-11. https://doi.org/10.1002/eet.530

Tàbara JD, Mangalagiu D, Kupers R, Jaeger CC, Mandel A, Paroussos L (2013) Transformative targets in sustainability policy-making: the case of the 30\% EU mitigation goal. J Environ Plan Manag 56(8): 1180-1191. https://doi.org/10.1080/09640568.2012.716365

Tàbara JD, St. Clair AL, Hermansen EAT (2017) Transforming communication and knowledge production processes to address high-end climate change. Environ Sci Policy 70:31-37. https://doi.org/10. 1016/j.envsci.2017.01.004

Tinch R, Schoumacher C, Grasso M, Grasso ME, Mandel A., Lamperti F, Napoletano M, Roventini A, Sapio A, Jäger J, Tàbara JD (2015). Evaluation of economic approaches under high-end scenarios. IMPRESSIONS Project Deliverable D5.1. Available at www. impressions-project.eu/documents/
Walker B, Holling CS, Carpenter SR, Kinzig A (2004) Resilience, adaptability and transformability in social-ecological systems. Ecol Soc 9(2): 5 [online] URL: http://www.ecologyandsociety.org/vol9/iss2/art5/

Walker B, Abel N, Anderies JM, Ryan P (2009) Resilience, adaptability, and transformability in the Goulburn-Broken Catchment, Australia. Ecol Soc 14(1):12 [online] URL: http://www.ecologyandsociety. org/vol14/iss 1/art12

Weaver PM, Haxeltine A, van de Kerkhof M, Tàbara JD (2006) Mainstreaming action on climate change through participatory appraisal. Int J Innov Sustain Dev 1(3):238-259. https://doi.org/10. 1504/IJISD.2006.012425

Westley F, Olsson P, Folke C, Homer-Dixon T, Vredenburg H, Loorbach D, Thompson J, Nilsson M, Lambin E, Sendzimir J, Banerjee B, Galaz V, van der Leeuw S (2011) Tipping toward sustainability: emerging pathways of transformation. Ambio 40(7):762-780. https://doi.org/10.1007/s13280-011-0186-9

Westley FR, Tjornbo O, Schultz L, Olsson P, Folke C, Crona B, Bodin Ö (2013) A theory of transformative agency in linked social-ecological systems. Ecol Soc 18(3):27. https://doi.org/10.5751/ES-05072180327

Wiek A, Ness B, Brand FS, Schweizer-Ries P, Farioli F (2012) From complex systems analysis to transformational change: a comparative appraisal of sustainability science projects. Sustain Sci 7(S1):5-24. https://doi.org/10.1007/s11625-011-0148-y 